
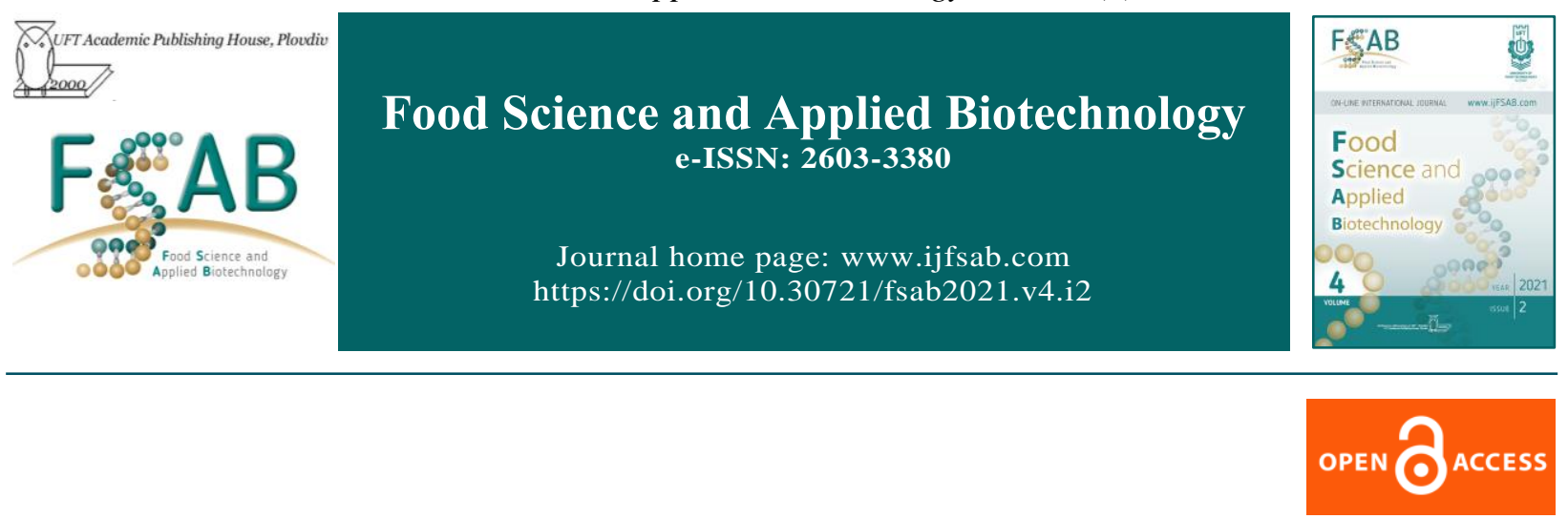

Research Article

\title{
Effect of process parameters of mashing on consumer properties and processability of polymalt extracts production process
}

\author{
Marina Mikulinich ${ }^{1 \boxminus}$, Natalya Azarenok ${ }^{1}$, Polina Bolotova ${ }^{1}$ \\ ${ }^{1}$ Department of merchandizing and organization of trade. Belarusian state university of food and chemical \\ Technologies. Mogilev. Belarus
}

\begin{abstract}
The development of the technology of viscous polymalt extracts using bare-grained oats will provide the human population with a functional food ingredient and products with specified consumer properties. Existing technologies to obtain of this kind type of extract did not consider the study of the influence of temperature conditions and the duration of the stages of mashing process, using bare-grained oats in its composition. Crops of Belarusian selection were used as raw materials: barley (Hordeum vulgare), baregrained oats (Avena ativa), wheat (Triticum aestivum) grain. Optimization of parameters in the production of polymalt wort based on barley, oat and wheat malt was carried out by regression analysis and weight coefficients. Dependencies of physico-chemical characteristics of oat-malt and polymalt worts on temperature and duration of mashing are established. These dependencies predict content of dry substances, maltose, amine nitrogen, protein and acidity in the process of production of worts. Optimal technological parameters were selected at the stage of barley-wheat-oat polymalt wort mashing, which made it possible to increase the dry substances by $12.5 \%$, maltose - by $21.3 \%$, protein - by $16.2 \%$ and filtration rate - by $25.0 \%$. The maximum solid content $14.4 \%$, maltose $11.4 \mathrm{~g} \cdot\left(100 \cdot \mathrm{cm}^{3}\right)^{-1}$, protein $1.22 \%$, in polymalt wort achieved under the following technological conditions: $(37 \pm 1)^{\circ} \mathrm{C}$ for 30 minutes, $(44 \pm 1)^{\circ} \mathrm{C}$ for 50 minutes, $(53 \pm 1)^{\circ} \mathrm{C}$ for 60 minutes, $(63 \pm 1)^{\circ} \mathrm{C}$ for 50 minutes, $(72 \pm 1)^{\circ} \mathrm{C}$ for 20 minutes and $(78 \pm 1)^{\circ} \mathrm{C}$ for 60 minutes.
\end{abstract}

Keywords: oat-malt wort, viscous polymalt extract, technological parameters of mashing, consumer properties, process optimization

${ }^{\square}$ Corresponding author: Associate Professor Marina Mikulinich, PhD in Technological Sciences, Department of merchandizing and organization of trade, Belarusian state university of food and chemical technologies, 3, Shmidt Avenue, 212027, Mogilev, Belarus, mobile: +375 2917231 25; tel.: 80222635 409;

E-mail: mikulinichmarina@gmail.com

\section{Article history:}

Received 6 April 2021

Reviewed 8 June 2021

Accepted 31 August 2021

Available on-line 10 October 2021

https://doi.org/10.30721/fsab2021.v4.i2.144 (C) 2021 The Authors. UFT Academic publishing house, Plovdiv 


\section{Introduction}

Special attention is paid by specialists from food science (Lisitsin et al. 2012; Gerasimenko et al. 2016; Kaishev and Seregin 2017; De and Tulipa 2019; Suboch 2019; Derkanosova et al. 2020; Suboch 2020; Bandy et al. 2020; Clark et al. 2020; Salar et al. 2020; Foley et al. 2021) to functional food ingredients and healthy foods, which reduce the risk of developing various diseases and ensure the entry of macro- and micronutrients into the body. In this aspect, viscous polymalt extracts that contain more than $10 \%$ to $15 \%$ of the daily intake of $B$ vitamins and minerals, as well as essential amino acids and easily digestible carbohydrates, become important. At the same time, polymalt extracts have a very wide field of application as an ingredient in the dairy, alcohol-free and confectionary industries as a sweetener, flavoring and preservative, including for increasing the consumer value of products.

A promising raw material for obtaining viscous polymalt extracts is bare-grained oats (Kriger et al. 2018; Li et al. 2020). On the one hand, it was easier to recycle it into malt due to its low husk content, and on the other hand, unlike other malts, it contained dextrinase. This promotes deeper hydrolysis of starch and other malt substances with mashing and an increase in the yield nutritive and biological value of the finished product. Previously, bare-grained oats were not used in the technology of extracts. At the same time, the use in the composition of barley and wheat malts allows to obtain a product with high quality indicators (Mikulinich et al. 2019; Dorsaf et al. 2020; Rico et al. 2020).

Research into the production of polymalt extract was carried out by scientists of Voronezh State University of Engineering Technologies, Altai State University named after I. I. Polzunov, Kiev Technical Institute of the Food Industry, etc. (Vostrikov et al. 2011; Korotkih et al. 2014; Lokhmatova and Kamenskaya 2018). However, depending on the individual characteristics of the malted raw materials used, their composition and the rheological characteristics of the extracts, the technological parameters of the production process differ.

An important step in the production of extracts is the process of producing polymalt wort. The temperature and duration of malt mashing significantly affect the integrity of this process. Properly selected temperature conditions ensure a more complete extraction of malt constituents, thereby the duration of saccharification and filtration reduce, increase in the yield and qualitative composition of wort.

The technological aspects of the production of polymalt wort with the combined mashing of barley, wheat and oat (husk) malt have been studied by Domaretsky (2011) and Emelyanova (1989), malt and polymalt worts - Meledina, Lokhmatova, Novikova. (Vostrikov et al. 2011; Chekina et al. 2015), Tsed et al. (2007), Korotkih et al. (2014). Malt mashing variants are based on a classic configuration adopted in the malt industry, including 4 temperature pauses: acid, protein, saccharification and mashout. However, for each malt and its further application, the temperature ranges and the duration of the mashing are different.

To maximize the extraction of all substances from malt to wort, it is necessary to use groups of cytolytic, proteolytic and amylolytic enzymes. It is, therefore, important to consider all stages when choosing technological regimes.

The authors (Domaretsky 2011, Emelyanova 1989) proposed a regime involves a mash of wheat, barley/corn and oat malt aging at temperature $44 \ldots 46^{\circ} \mathrm{C}$ for $30-45 \mathrm{~min}, 51 \ldots 53^{\circ} \mathrm{C}-15-30 \mathrm{~min}$, $62 \ldots 64^{\circ} \mathrm{C}-45-60 \mathrm{~min}, 71 \ldots 73^{\circ} \mathrm{C}-$ not more than 30 $\min , 76 \ldots 78^{\circ} \mathrm{C}-10-15 \mathrm{~min}$. However, it should be removed and marked, that the composition included oat malt obtained husk oats, which significantly affects the technological process.

Novikova et al. (2014) proposed a regime involves a mash of barley, triticale/corn and buckwheat malt aging at temperature of $42 \ldots 45^{\circ} \mathrm{C}$ for $40-45 \mathrm{~min}$, $52 \ldots . .55^{\circ} \mathrm{C}-40-45 \min , 63^{\circ} \mathrm{C}-60 \min , 70 \ldots .72^{\circ} \mathrm{C}-$ no more than $30 \mathrm{~min}, 76 \ldots 78^{\circ} \mathrm{C}-10-15 \mathrm{~min}$.

Analysis of literature sources showed that for barley and wheat malt optimal temperature ranges for enzyme action are known (Goode et al. 2005; Alyabiev et al. 2016; Panova et al. 2016; Cornaggia et al. 2019; Sun et al. 2020); for oat malt obtained from bare-grained oats, data are not unambiguous (Tsed et al. 2007; Chekina et al. 2015) and depend on its further application. 
Chekina et al. (2015) proposed a method of mashing, involving preparation of a mash from oat malt at a temperature of $65 \ldots 67^{\circ} \mathrm{C}$ for $60 \mathrm{~min}$, $72 \ldots 73^{\circ} \mathrm{C}-30 \mathrm{~min}$ and $78^{\circ} \mathrm{C}-10 \mathrm{~min}$. This makes it possible to obtain wort with high concentration of maltose, which is later used for production of oat syrup.

The authors (Tsed et al. 2007) proposed a method of treating oat malt obtained from bare-grained oats, involving water-heat treatment at $90^{\circ} \mathrm{C}$ for 100 minutes, cooling the mass to $56^{\circ} \mathrm{C}$ and saccharification at this temperature. This made it possible to get a mash with good mobility for its further processing into alcohol wort.

The data show that existing polymalt extracts production technologies, including previous studies of the authors (Morgunova and Mikulinich 2015; Mikulinich et al. 2019), do not affect the study of technological parameters at the stage of mashing, taking into account the use of bare-grained oats in its composition.

The purpose of the work is to develop the technology of polymalt extracts from malts of grain raw materials, which make it possible to increase the efficiency of using domestic grain raw materials and provide the population with a quality product with the specified consumer properties.

The scientific task is to evaluate the technological properties of polymalt wort using malt from baregrained oats, wheat and barley, and to establish optimal temperature conditions and the duration of mashing in the production of extract to increase the consumer properties and technological process.

\section{Materials and Methods}

The object of the study was technological parameters of wort production using bare-grained oats.

The subject of the research was relationship of qualitative indicators of malt and polymalt worts with technological parameters at the mashing stage.

The object of experimental studies was samples of polymalt wort based on barley, oat, wheat malt and malt wort obtained from oat malt. Wort was prepared from fresh-dried malts obtained in the laboratory of the Department of Commodity
Science and Trade Organization of the Belarusian state university of food and chemical Technologies. The polymalt wort was prepared from the above crushed malts in a weight ratio of 1:1:1. Crops of Belarusian selection were used as raw materials: barley (Hordeum vulgare) of "Fest" variety, baregrained oats (Avena sativa) of "Gosha" variety, wheat (Triticum aestivum) grain of "Sudarynya" variety. Grinding of malt was carried out with the help of a laboratory mill LM 202. The resulting crushed malted raw materials was divided into fractions by sieving through a steel wire sieves for 5 minutes shaking at 300 vibrations per minute.

Three sieves with different diameters of holes were used to separate the grinding of wheat and oat malt: 1-st - $2.2 \mathrm{~mm}$; 2-nd - $1.0 \mathrm{~mm}, 3$-rd - $0.56 \mathrm{~mm}$; barley malt sieve with hole diameter: 1 -st -1.25 $\mathrm{mm}$; 2-nd - $1.0 \mathrm{~mm}, 3-\mathrm{rd}-0.56 \mathrm{~mm}$.

The residue on the sieve with a hole diameter of 2.2 $\mathrm{mm}$ was attributed to coarse grits, the residue on the sieve with a hole diameter of $1.0 \mathrm{~mm}$ - medium grits, the residue on the sieve with a hole diameter of $0.56 \mathrm{~mm}$ - fine grits, the residue from the sieve with a hole diameter of $0.56 \mathrm{~mm}$ - flour (for wheat and oat malt).

The residue on the sieve with a diameter of holes of $1.25 \mathrm{~mm}$ was attributed to husks, the residue on the sieve with a diameter of holes of $1.0 \mathrm{~mm}$ - to coarse grits, the residue on the sieve with a diameter of holes of $0.56 \mathrm{~mm}$ - fine grits, the residue from the sieve with a diameter of holes of $0.56 \mathrm{~mm}-$ flour (for barley malt).

Sieve sizes for classification of ground wheat and oat malts are taken according to (Domaretsky 2011), for barley malt - (Ermolaeva 2004).

A malt and polymalt worts was infused at the hydromodule 1:5. The following fractional composition was used at mashing oat malt: a coarse grist $-10 \%$, an medium size grist $-30 \%$, a fine grist $-30 \%$, flour $-30 \%$. Mashing of three malts in combination, the fractional composition of the baregrained raw material was: a coarse grist $-15 \%$, an medium size grist $-15 \%$, a fine grist $-40 \%$ and flour - 30\% (Morgunova and Mikulinich 2015).

The content of dry substances was determined by the refractometric method (Kosminsky 2001). 
The content maltose was determined by the Bertrand method, the essence of which is the reduction of copper (II) from Feling's solution to copper (I) by sugars. The isolated reddish-brown precipitate $\mathrm{Cu}_{2} \mathrm{O}$ was dissolved in an acidic solution of $\mathrm{Fe}_{2}\left(\mathrm{SO}_{4}\right)_{3}$ and the equivalent amount of $\mathrm{FeSO}_{4}$ formed was titrated with $0.1 \mathrm{~mol} \cdot\left(\mathrm{dm}^{3}\right)^{-1}$ solution of $\mathrm{KMnO}_{4}$ (Kosminsky 2001; Ermolaeva 2004).

The protein content was determined by the Kjeldahl method using an automatic Kejeltec 2000 unit. The essence of a method consists in a mineralization of organic matter sulfuric acid with the presence of the catalyst with generating of $\left(\mathrm{NH}_{4}\right)_{2} \mathrm{SO}_{4}$, destruction $\left(\mathrm{NH}_{4}\right)_{2} \mathrm{SO}_{4}$ alkali with allocation of $\mathrm{NH}_{4} \mathrm{OH}$, steaming off $\mathrm{NH}_{4} \mathrm{OH}$ with water vapor in $\mathrm{H}_{2} \mathrm{SO}_{4}$ solution with the subsequent titration (Ermolaeva 2004).

The determination of amine nitrogen was carried out in a "copper method" based on the ability of most amino acids and peptides to form soluble complex compounds with copper. Excess copper was distilled and its amount equivalent to amine nitrogen was converted to acetic acid salt and quantified by iodometric titration (Kosminsky 2001; Ermolaeva 2004).

The filtration rate of the laboratory wort was determined by the volume of wort passed through a paper filter of average filtration FA-III in 60 minutes (Kosminsky 2001), the duration of saccharification - by an iodine solution, the acidity of the laboratory wort - by titration with 0.1 $\mathrm{mol} \cdot\left(\mathrm{dm}^{3}\right)^{-1}$ sodium hydroxide solution (Ermolaeva 2004).

The experiment was carried out in 2 stages: at the first stage, technological parameters for oat wort were studied, at the second stage-for polymalt wort. The value of the temperature and the duration of the mashing took on the basis of the technological regimes studied during the analysis for oat malt obtained from bare-grained oats. Constant technological modes were for acid pause $-37^{\circ} \mathrm{C}, 30$ minutes, saccharification stages at a temperature of $72^{\circ} \mathrm{C}$ - no more than 30 minutes and mashout pause $-78^{\circ} \mathrm{C}$, 60 minutes; values at the following temperatures $-40 \ldots 45^{\circ} \mathrm{C}, 50 \ldots 55^{\circ} \mathrm{C}, 62 \ldots 65^{\circ} \mathrm{C}$ for 60 minutes. Samples were taken to determine the physicochemical values of oat and polymalt oats every 20 minutes. The temperature between the pauses was raised at $1{ }^{\circ} \mathrm{C}$ per minute.
In order to solve the problem of optimizing parameters in obtaining polymalt wort, methods of re-gression analysis and weight coefficients were applied (Morgunova 2000; Grachev 2005; Mikulinich et al. 2016). To determine a generalized indicator, all indicators were brought to a single scale and dimensionless appearance according to the formula:

$$
\begin{aligned}
\mathrm{Y}_{\mathrm{n}}(\tau)= & \left(\mathrm{Y}_{\text {solid matter }}(\tau), \mathrm{Y}_{\text {amine nitrogen }}(\tau),\right. \\
& \left.\mathrm{Y}_{\text {maltose }}(\tau), \mathrm{Y}_{\text {acidity }}(\tau)\right),
\end{aligned}
$$

where:

$n$ is the generalized quality indicator at a certain mashing temperature;

$\tau$ is the duration of malts mashing.

Conversion of indicators to a single scale was carried out according to the formula:

$\widetilde{Y_{\tau n}}=\frac{\left|y_{\tau n}-y_{n}^{*}\right|}{y_{n}^{*}}$

where:

$\tilde{Y}_{t n}$ is the converted value of the $n$-th indicator at $\tau$ minutes;

$y_{\tau n}$ is the value of the $n$-th indicator at $\tau$-minutes;

$y_{n}{ }_{n}$ is the control value of the $n$-th indicator at $\tau$ minutes.

A single criterion of optimality was calculated by the formula:

$$
Y_{\tau}=\sum_{n=1}^{4} a_{n} \widetilde{Y_{\tau n}}
$$

where:

$Y_{\tau}$ is the optimality criterion at $\tau$-minutes;

$a_{n}$ is the weighting factor equal to 0.25 for each indicator.

Analytical determination for each test are executed in 3-fold repeatability. Experimental data processing was carried out by methods of mathematical statistics with use of standard computer programs.

\section{Results and Discussion}

Influence of temperature and duration of mashing of oat malt obtained from bare-grained oats on 
physico-chemical indices of wort in temperature range $40 \ldots 65^{\circ} \mathrm{C}$. The results are in Table 1 .

Analyzing the results presented in table 1, it was noted that an increase in the temperature and duration of mashing increased the acidity, solid matter content, protein throughout the process and maximum values were observed at a temperature of $65^{\circ} \mathrm{C}$ and a duration of mashing of 60 minutes. An increase in the process parameters contributed to an increase in the amine nitrogen content until the temperature of $50^{\circ} \mathrm{C}$ and a maximum value was observed at a mashing duration of 60 minutes and amounted to $18.6 \mathrm{mg} \cdot\left(100 \cdot \mathrm{cm}^{3}\right)^{-1}$ of oat wort. However, after $50^{\circ} \mathrm{C}$, the amine nitrogen content decreased, possibly due to the action of proteolytic enzymes.

The maximum maltose content was observed at a temperature of $62^{\circ} \mathrm{C}$ and a mashing time of 60 minutes and was $10.1 \mathrm{~g} \cdot\left(100 \cdot \mathrm{cm}^{3}\right)^{-1}$ of oat wort.

The results obtained in the study are consistent with the authors' (Chekina et al. 2015).

Table 1. Results of influence of technological parameters of mashing on physico-chemical indices of oat-malt wort

\begin{tabular}{|c|c|c|c|c|c|c|c|}
\hline \multirow{2}{*}{ Quality indicators } & \multirow{2}{*}{$\begin{array}{c}\tau, \\
\text { minutes }\end{array}$} & \multicolumn{6}{|c|}{ Temperature, ${ }^{\circ} \mathrm{C}$} \\
\hline & & 40 & 45 & 50 & 55 & 62 & 65 \\
\hline \multirow[t]{3}{*}{ Solid matter content, $\%$} & 20 & $3,0 \pm 0,1$ & $4,0 \pm 0,1$ & $6,0 \pm 0,1$ & $7,8 \pm 0,1$ & $9,9 \pm 0,1$ & $11,4 \pm 0,1$ \\
\hline & 40 & $3,6 \pm 0,1$ & $4,0 \pm 0,1$ & $6,2 \pm 0,1$ & $7,9 \pm 0,1$ & $11,0 \pm 0,1$ & $12,4 \pm 0,1$ \\
\hline & 60 & $4,0 \pm 0,1$ & $4,6 \pm 0,1$ & $6,4 \pm 0,1$ & $8,5 \pm 0,1$ & $12,0 \pm 0,1$ & $13,5 \pm 0,1$ \\
\hline \multirow{3}{*}{$\begin{array}{l}\text { Amine nitrogen content, } \\
\mathrm{mg} \cdot\left(100 \cdot \mathrm{cm}^{3}\right)^{-1} \text { of wort }\end{array}$} & 20 & $11,9 \pm 0,5$ & $12,8 \pm 0,5$ & $13,1 \pm 0,5$ & $12,3 \pm 0,5$ & $12,2 \pm 0,5$ & $10,7 \pm 0,4$ \\
\hline & 40 & $12,5 \pm 0,5$ & $13,5 \pm 0,5$ & $14,4 \pm 0,6$ & $14,4 \pm 0,6$ & $14,8 \pm 0,6$ & $12,7 \pm 0,6$ \\
\hline & 60 & $12,9 \pm 0,6$ & $14,2 \pm 0,6$ & $18,6 \pm 0,7$ & $16,9 \pm 0,7$ & $16,2 \pm 0,7$ & $15,4 \pm 0,6$ \\
\hline \multirow{3}{*}{$\begin{array}{l}\text { Maltose content, } \\
\mathrm{g} \cdot\left(100 \cdot \mathrm{cm}^{3}\right)^{-1} \text { of wort }\end{array}$} & 20 & $1,2 \pm 0,1$ & $3,2 \pm 0,1$ & $3,4 \pm 0,1$ & $4,2 \pm 0,1$ & $6,6 \pm 0,1$ & $9,0 \pm 0,1$ \\
\hline & 40 & $2,1 \pm 0,1$ & $4,3 \pm 0,1$ & $3,6 \pm 0,1$ & $6,6 \pm 0,1$ & $8,4 \pm 0,1$ & $8,9 \pm 0,1$ \\
\hline & 60 & $3,1 \pm 0,1$ & $4,6 \pm 0,1$ & $5,0 \pm 0,1$ & $6,6 \pm 0,1$ & $10,1 \pm 0,1$ & $9,6 \pm 0,1$ \\
\hline \multirow[t]{3}{*}{ Protein content, $\%$} & 20 & $0,14 \pm 0,01$ & $0,21 \pm 0,01$ & $0,26 \pm 0,01$ & $0,76 \pm 0,01$ & $0,78 \pm 0,01$ & $0,79 \pm 0,01$ \\
\hline & 40 & $0,16 \pm 0,01$ & $0,24 \pm 0,01$ & $0,35 \pm 0,01$ & $0,94 \pm 0,02$ & $0,94 \pm 0,03$ & $1,05 \pm 0,03$ \\
\hline & 60 & $0,16 \pm 0,01$ & $0,36 \pm 0,01$ & $0,41 \pm 0,01$ & $0,96 \pm 0,02$ & $1,11 \pm 0,03$ & $1,26 \pm 0,03$ \\
\hline \multirow{3}{*}{$\begin{array}{l}\text { Acidity, ac. unid }\left(\mathrm{cm}^{3} \text { of } 1\right. \\
\text { mol } \cdot \mathrm{dm}^{3} \text { of sodium } \\
\text { hydroxide solution on } 100 \\
\left.\mathrm{~cm}^{3} \text { of wort }\right)\end{array}$} & 20 & $1,5 \pm 0,1$ & $1,6 \pm 0,1$ & $1,9 \pm 0,1$ & $2,1 \pm 0,1$ & $2,2 \pm 0,1$ & $2,2 \pm 0,1$ \\
\hline & 40 & $1,7 \pm 0,1$ & $1,8 \pm 0,1$ & $2,2 \pm 0,1$ & $2,3 \pm 0,1$ & $2,5 \pm 0,1$ & $2,5 \pm 0,1$ \\
\hline & 60 & $1,7 \pm 0,1$ & $1,8 \pm 0,1$ & $2,1 \pm 0,1$ & $2,3 \pm 0,1$ & $2,5 \pm 0,1$ & $2,6 \pm 0,1$ \\
\hline
\end{tabular}

The processing of experimental data made it possible to obtain equations establishing the dependence of acidity, solids content, maltose, amine nitrogen, protein on temperature and duration of mashing in the form of:

$$
\mathrm{y}=\mathrm{k}_{0} \cdot \mathrm{x}_{3}+\mathrm{k}_{1} \cdot \mathrm{x}_{2}+\mathrm{k}_{2} \cdot \mathrm{x}+\mathrm{b},
$$

where:

$y \in\left\{y_{1}, y_{2}, y_{3}, y_{4}, y_{5}\right\} ; y_{1}$ is the solids content, \%; $y_{2}$ is the amine nitrogen content, $\mathrm{mg} \cdot\left(100 \cdot \mathrm{cm}^{3}\right)^{-1}$ of wort; $y_{3}$ is the maltose content, $\mathrm{g} \cdot\left(100 \cdot \mathrm{cm}^{3}\right)^{-1}$ of wort; $y_{4}$ is the protein content, $\% ; y_{5}$ is the acidity, a. un.; $k_{0}, k_{1}, k_{2}$ is the coefficients of the equation; $x$ is the duration of mashing, minutes; $b$ is the absolute term.

The coefficient values for equation (4) are in Table 2 and range from 0.97 to 0.99 , indicating a high degree of agreement of the regression equation with the actual values. 
Table 2. Coefficient values of equation (4) at different modes of mashing

\begin{tabular}{|c|c|c|c|c|c|c|c|c|c|c|c|c|}
\hline \multirow{3}{*}{$\begin{array}{l}\text { Quality } \\
\text { indicators }\end{array}$} & \multicolumn{12}{|c|}{ Coefficient values of equations } \\
\hline & \multicolumn{4}{|c|}{ Mode 1} & \multicolumn{4}{|c|}{ Mode 2} & \multicolumn{4}{|c|}{ Mode 3} \\
\hline & $k_{0}$ & $k_{l}$ & $k_{2}$ & $b$ & $k_{0}$ & $k_{1}$ & $k_{2}$ & $b$ & $k_{0}$ & $k_{I}$ & $k_{2}$ & $b$ \\
\hline$y_{1}$ & $-0,0602$ & 0,6837 & $-0,5132$ & 2,8667 & $-0,1093$ & 1,3008 & $-2,6328$ & 5,0333 & $-0,1176$ & 1,4365 & $-3,0888$ & 5,8333 \\
\hline$y_{2}$ & 0,0130 & $-0,379$ & 1,8652 & 10,43 & $-0,0750$ & 0,475 & $-0,0500$ & 12,20 & 0,0491 & $-1,067$ & 5,8981 & 7,63 \\
\hline$y_{3}$ & 0,1125 & $-1,0004$ & 3,7271 & $-1,550$ & $-0,0600$ & 0,6600 & $-0,7071$ & 2,520 & $-0,1121$ & 1,225 & $-2,4500$ & 4,727 \\
\hline$y_{4}$ & $-0,0258$ & 0,2637 & $-0,6136$ & 0,5313 & $-0,0284$ & 0,2879 & $-0,6320$ & 0,5355 & $-0,0202$ & 0,1952 & $-0,3338$ & 0,3350 \\
\hline$y_{5}$ & $-0,0138$ & 0,1161 & $-0,0887$ & 1,470 & $-0,0101$ & 0,0839 & 0,0154 & 1,550 & $-0,0129$ & 0,1207 & $-0,1157$ & 1,695 \\
\hline
\end{tabular}

Note:

Mode $1-\frac{40 \div 45^{\circ} \mathrm{C}}{20^{\prime}}-\frac{44^{\circ} \mathrm{C}}{50^{\prime}}-\frac{50 \div 55^{\circ} \mathrm{C}}{20^{\prime}}-\frac{53^{\circ} \mathrm{C}}{50^{\prime}}-\frac{62 \div 65^{\circ} \mathrm{C}}{20^{\prime}}-\frac{63^{\circ} \mathrm{C}}{50^{\prime}}$

Mode $2-\frac{40 \div 45^{\circ} \mathrm{C}}{40^{\prime}}-\frac{44^{\circ} \mathrm{C}}{50^{\prime}}-\frac{50 \div 55^{\circ} \mathrm{C}}{40^{\prime}}-\frac{53^{\circ} \mathrm{C}}{50^{\prime}}-\frac{62 \div 65^{\circ} \mathrm{C}}{40^{\prime}}-\frac{63^{\circ} \mathrm{C}}{50^{\prime}}$

Mode $3-\frac{40 \div 45^{\circ} \mathrm{C}}{60^{\prime}}-\frac{44^{\circ} \mathrm{C}}{50^{\prime}}-\frac{50 \div 55^{\circ} \mathrm{C}}{60^{\prime}}-\frac{53^{\circ} \mathrm{C}}{50^{\prime}}-\frac{62 \div 65^{\circ} \mathrm{C}}{60^{\prime}}-\frac{63^{\circ} \mathrm{C}}{50^{\prime}}$

The obtained equations can be used for into account the results of the first experience, the determination of physicochemical indices in the following process modes at the stage of oat malt production process of oat-malt wort by calculation mashing can be recommended, (Fig. 1), the method and prediction of physicochemical indices temperature conditions of which are based on in the process of oat-malt wort production. Taking combined mashing of malts.

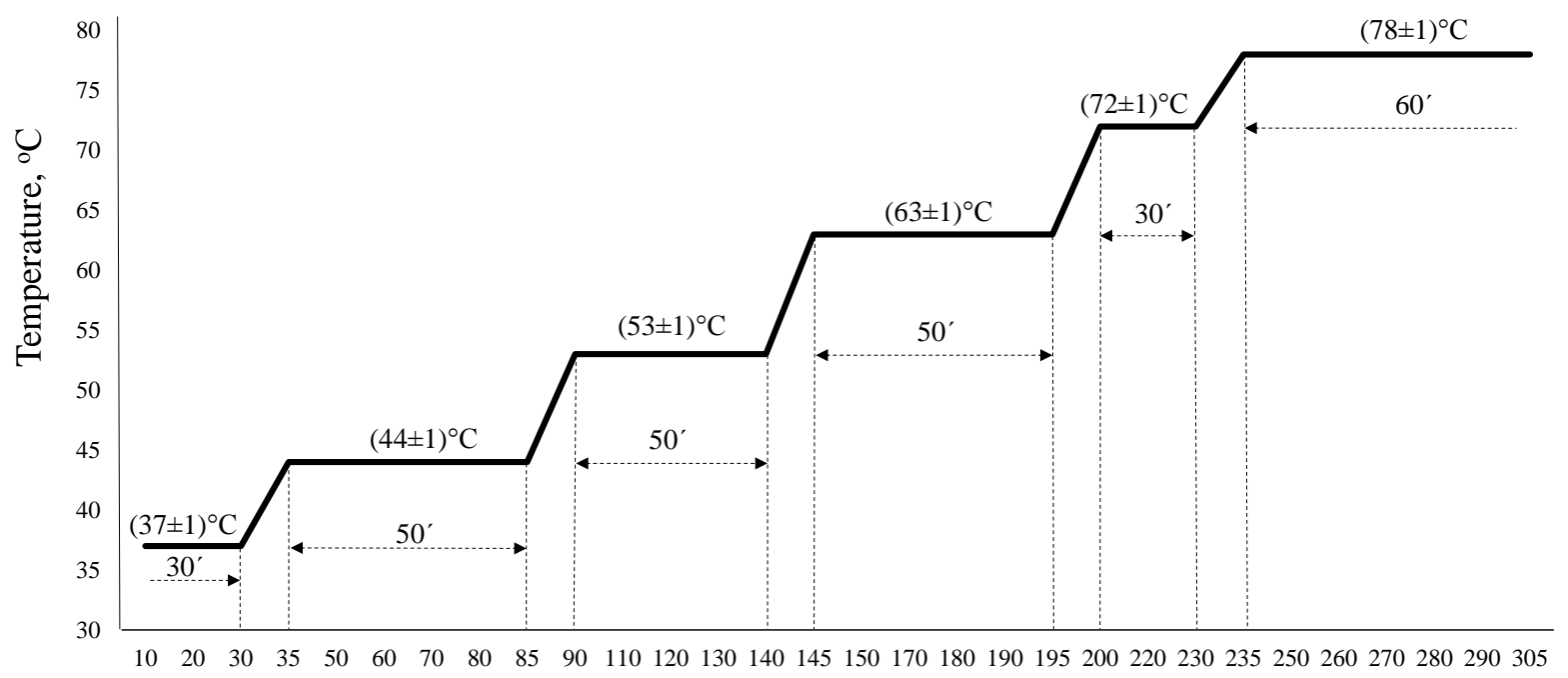

Duration, minutes

Figure 1. Technological modes of mashing of oat-malt wort using bare-grained oats 
The results of qualitative indicators of oat-malt wort in accordance with the selected technological regimes showed that the duration of saccharification is in the permissible range of $25-28$ minutes. The content of dry substances was $12.2 \%$, maltose -9.2 $\mathrm{g} \cdot\left(100 \cdot \mathrm{cm}^{3}\right)^{-1}$ of wort, protein $-0.95 \%$, amine nitrogen $-15.2 \mathrm{mg} \cdot\left(100 \cdot \mathrm{cm}^{3}\right)^{-1}$ of wort; acidity 2.5 a. un. It is noted that malt wort obtained from bare-grained oats has a low filtration rate (less than $\left.100 \mathrm{~cm}^{3} \cdot \mathrm{h}^{-1}\right)$, which is consistent with the data (Chekina et al. 2015) and is associated with the low temperature of gleistening of oat starch, as well as the content of a significant amount of $\beta$-glucan in the composition and possibly a low content of a set of enzymes for its cleavage. The filtration rate is estimated as "normal" when, after returning $100 \mathrm{~cm}^{3}$ of the first portion of filtrate, the wort passes through the filter in 60 minutes. Otherwise, the filtration can be estimated as slow or very slow. Therefore, it is recommended to mash oat malt in the composition of malts, and to use enzymatic preparations in the production of oat-malt wort.

At the next stage, the effect of the duration of comashing of malts in the production of polymalt wort for protein pause $-44^{\circ} \mathrm{C}$ for 60 minutes, $53^{\circ} \mathrm{C}$ for 60 minutes, and at the saccharification stage $-63^{\circ} \mathrm{C}$ for 60 minutes, on the physicochemical parameters of wort was studied. Results of study of influence of technological modes of malt mashing on physicochemical indicators of barley-wheat-oat of polymalt wort are presented in Figure 2.

Analyzing the results presented in Figure 2 it was noted that with an increase in temperature from 44 to $63^{\circ} \mathrm{C}$ and a duration of mashing from 10 to 60 minutes, the acidity, content of solid matter, maltose and amine nitrogen increased in $1.9 ; 2.9 ; 5.6 ; 1.1$ times, respectively.

The greatest changes in the content of amine nitrogen occurred at a temperature of $53^{\circ} \mathrm{C}$ and the maximum concentration was observed at a mashing duration of 20 minutes and amounted to 39.2 $\mathrm{mg} \cdot\left(100 \cdot \mathrm{cm}^{3}\right)^{-1}$ of wort. After 20 minutes of mashing the content of amine nitrogen decreased and by the end of the process was 29.4 $\mathrm{mg} \cdot\left(100 \cdot \mathrm{cm}^{3}\right)^{-1}$ of wort; the largest changes in the content of maltose - at a temperature of $63^{\circ} \mathrm{C}$ and by the end of the process, the composition was 11.1 $\mathrm{g} \cdot\left(100 \cdot \mathrm{cm}^{3}\right)^{-1}$ of wort, which is explained by the optimal temperature for the action of amylolytic enzymes, in particular $\beta$-amylase. The solid matter content during the mashing process at temperatures of $44^{\circ} \mathrm{C}$ and $53^{\circ} \mathrm{C}$ increased uniformly, however, at a temperature of $63^{\circ} \mathrm{C}$, the value varied most intensively. This may be due to intensive hydrolysis of starch.

The values of the coefficients for the equation shown in Figure 2 range from 0.81 to 0.99, indicating a high degree of agreement of the regression equation with the actual values.

The obtained equations can be used to determine the content of solid matter, maltose, amine nitrogen and acidity by calculation and to predict physicochemical parameters in the process of polymalt wort production. Using the regression analysis method, a generalized indicator in the form of a third-degree polynomial was obtained for various technological parameters of mashing.

This allows to determine the minimum of functions (Y) (the mashing process is completed when the generalized indicator reaches the minimum value):

$$
\begin{array}{r}
Y_{1}=0,0031 \cdot x^{3}-0,0312 \cdot x^{2}+0,0472 \cdot x+0,1579 \quad(5) \\
\left(R^{2}=0,99\right) \\
Y_{2}=-0,0015 \cdot x^{3}+0,022 \cdot x^{2}-0,1081 \cdot x+0,2321 \quad(6) \\
\left(R^{2}=0,99\right) \\
Y_{3}=0,0012 \cdot x^{3}-0,0082 \cdot x^{2}+0,0309 \cdot x+0,2138
\end{array}
$$

where:

$Y_{l}$ is the generalized quality indicator at mashing temperature $44^{\circ} \mathrm{C}$;

$Y_{2}$ is the generalized quality indicator at mashing temperature $53^{\circ} \mathrm{C}$;

$Y_{3}$ is the generalized quality indicator at mashing temperature $63^{\circ} \mathrm{C}$;

$x$ is the duration of malts mashing. 

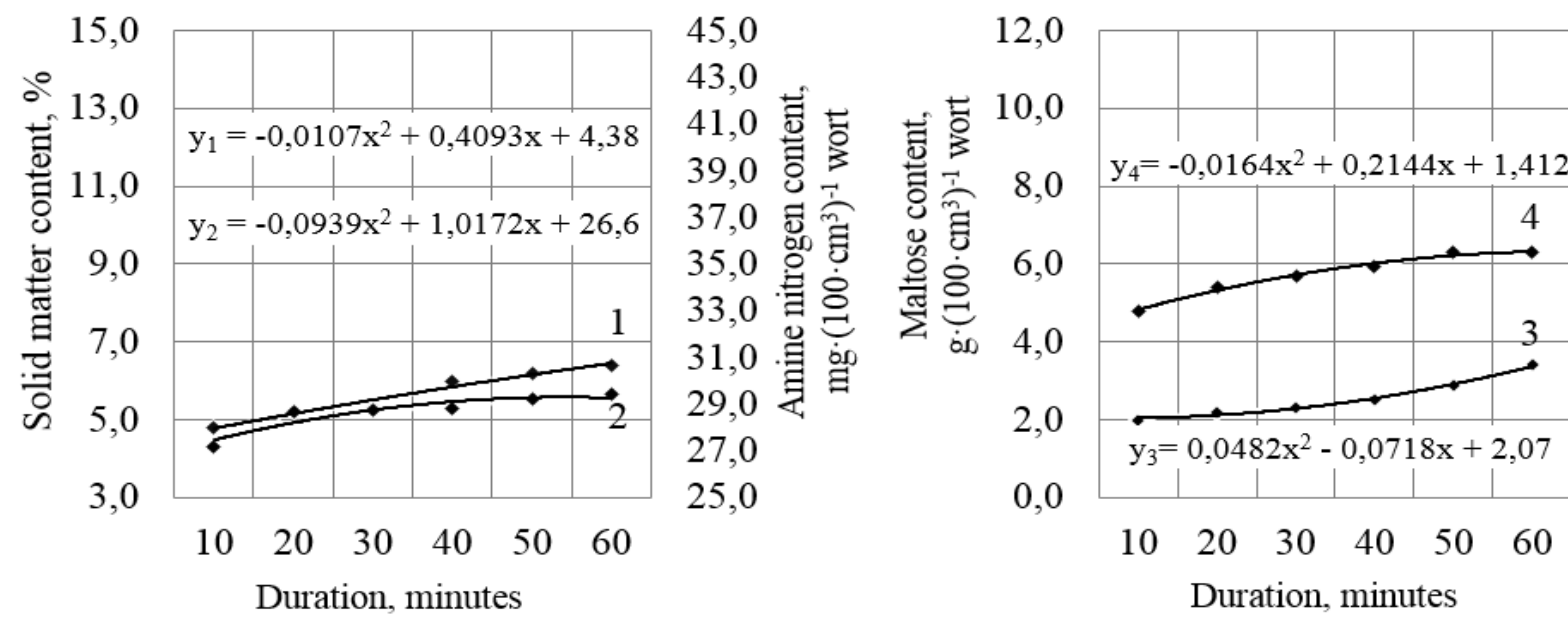

4,0

3,5

3,0 兽
2,5 它
2,0 窝
1,5

1,0

at temperature $44^{\circ} \mathrm{C}$

0,5

0,0

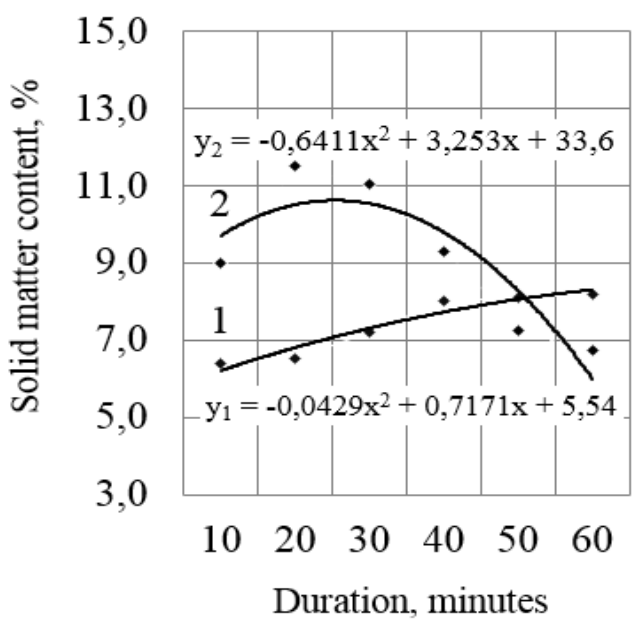

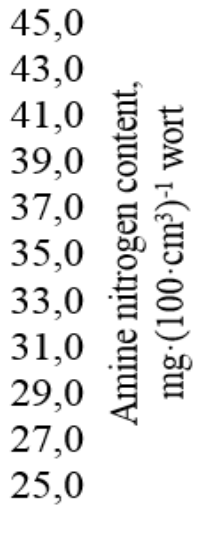

at temperature $53^{\circ} \mathrm{C}$
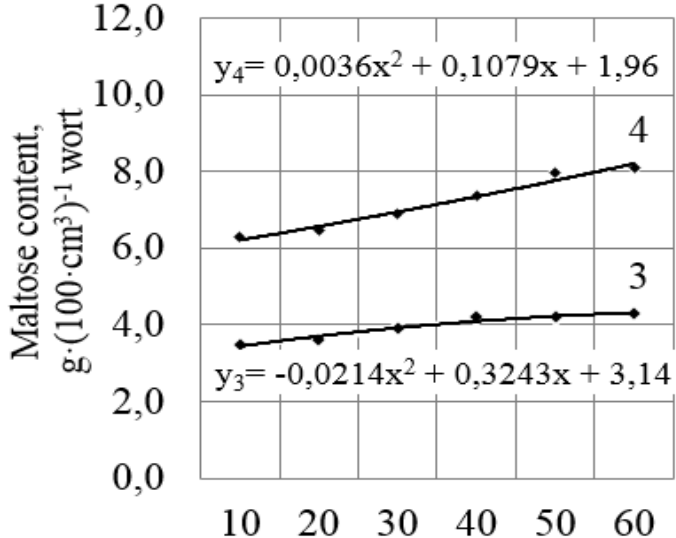

Duration, minutes

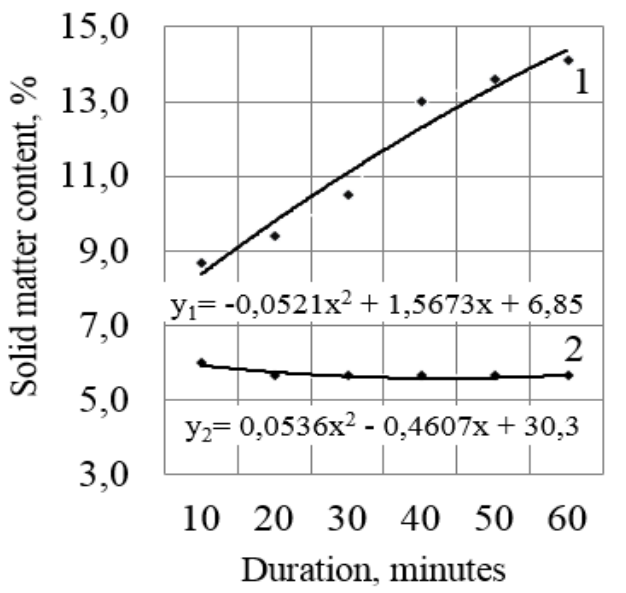

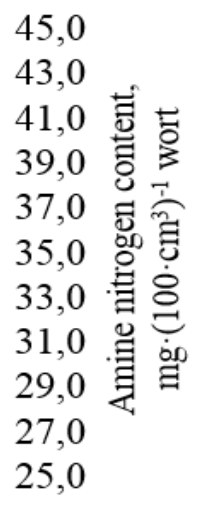

at temperature $63^{\circ} \mathrm{C}$
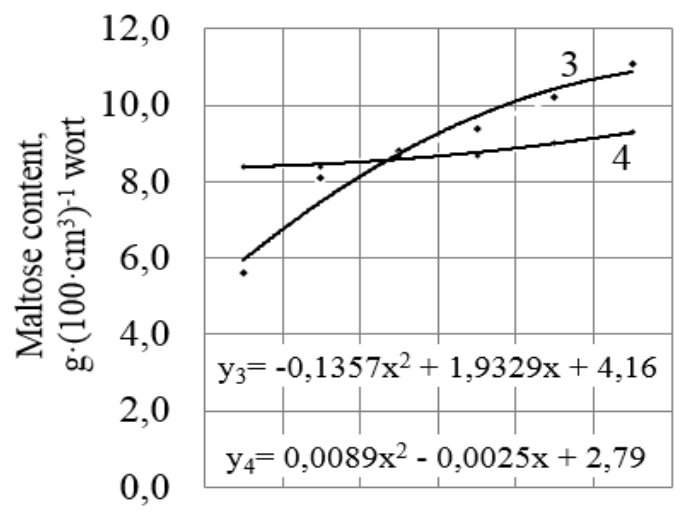

4,0

3,0 苇

再

2,0 莺

$y_{3}=-0,1357 x^{2}+1,9329 x+4,16 \quad 1,0$

$\mathrm{y}_{4}=0,0089 \mathrm{x}^{2}-0,0025 \mathrm{x}+2,79$

0,0

Duration, minutes

1 - solid matter, 2 - amine nitrogen, 3 - maltose, 4 - acidity

Figure 2. Influence of temperature and duration of mashing on physico-chemical indices of barley-wheat-

oat of polymalt wort 


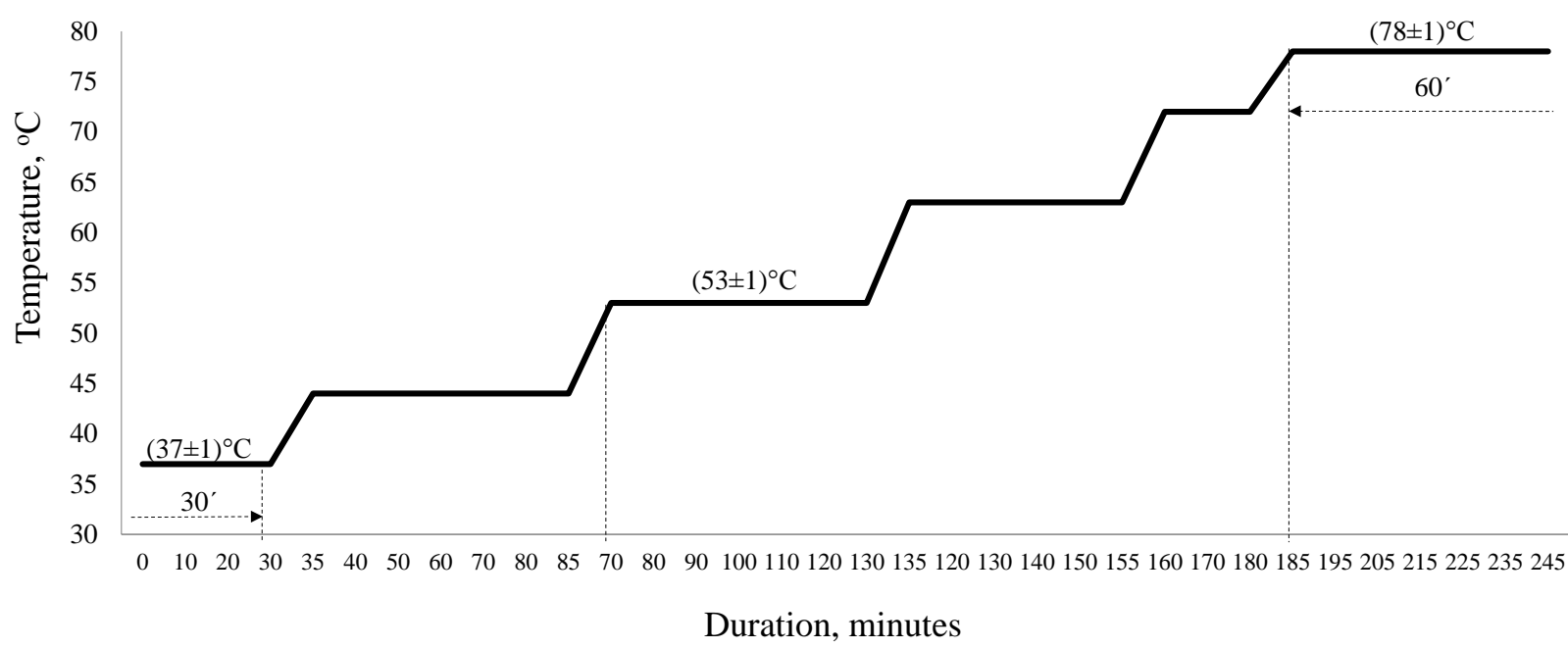

Figure 3. Technological modes of mashing of barley-wheat-oat of polymalt wort using bare-grained oats

As a result of the processing of the equations, the optimal mashing mode for the polymalt wort shown in Figure 3 is determined. It is different from the existing duration of the protein and maltose pauses. Results of qualitative indicators of barley-wheat-oat of polymalt wort according to selected technological modes as compared to control are given in Table 4. As a control, a sample of barleywheat-oat of polymalt wort obtained by the author according to the technological regimes proposed by Domaretsky (2011) was used.

Table 4. Physico-chemical parameters of barleywheat-oat of polymalt wort in accordance with the selected technological modes

\begin{tabular}{|l|c|c|}
\hline \multicolumn{1}{|c|}{ Quality indicators } & Control & $\begin{array}{c}\text { Polymalt } \\
\text { wort }\end{array}$ \\
\hline $\begin{array}{l}\text { Saccharification duration, } \\
\text { min }\end{array}$ & $15-20$ & $10 \pm 2$ \\
\hline Filtration rate, $\mathrm{cm}^{3} \cdot \mathrm{h}^{-1}$ & 240 & $300 \pm 10$ \\
\hline Solid matter content, \% & 12,8 & $14,4 \pm 0,1$ \\
\hline $\begin{array}{l}\text { Amine nitrogen content, } \\
\mathrm{mg} \cdot\left(100 \cdot \mathrm{cm}^{3}\right)^{-1} \text { of wort }\end{array}$ & 38,0 & $34,0 \pm 1,2$ \\
\hline $\begin{array}{l}\text { Maltose content, } \\
\mathrm{g} \cdot\left(100 \cdot \mathrm{cm}^{3}\right)^{-1} \text { of wort }\end{array}$ & 9,4 & $11,4 \pm 0,1$ \\
\hline Protein content, \% & 1,05 & $1,22 \pm 0,02$ \\
\hline
\end{tabular}

Analysis of the experimental data presented in Table 4 showed that the process modes of mashing selected during the studies made it possible to increase the content of solid matter by $12.5 \%$ compared to the control, the filtration rate by $25.0 \%$, the content of maltose by $21.3 \%$ and protein by $16.2 \%$.

\section{Conclusions}

Physico-chemical indices of oat-malt and barleywheat-oat of polymalt worts depending on temperature and duration of mashing are investigated. Dependencies of solid matter, maltose, amine nitrogen, protein and acidity on temperature and prolonged mashing are determined. Optimal temperatures and duration of mashing during production of oat-malt and polymalt worts are selected. It is recommended for the production of polymalt extract based on barley malt, bare-grained oats and wheat, to carry out mashing at the following modes: $37^{\circ} \mathrm{C}$ for 30 minutes; $(44 \pm 1)^{\circ} \mathrm{C}$ for 50 minutes, $(53 \pm 1)^{\circ} \mathrm{C}$ for 60 minutes; $(63 \pm 1)^{\circ} \mathrm{C}$ for 50 minutes, $(72 \pm 1)^{\circ} \mathrm{C}$ for not more than 30 minutes; $(78 \pm 1)^{\circ} \mathrm{C}$ for 60 minutes. Qualitative indices of barley-wheat-oat polymalt wort are characterized by high technological properties (saccharification duration - 10 minutes, solid matter content $-14.4 \%$, maltose $-11.4 \mathrm{~g} \cdot\left(100 \cdot \mathrm{cm}^{3}\right)^{-1}$ of wort, protein $-1.22 \%$, amine nitrogen -34.0 $\mathrm{mg} \cdot\left(100 \cdot \mathrm{cm}^{3)-1}\right.$ of wort $)$. 


\section{References}

Alyabiev B.A., Rostovskaya M.F., Prikhodko Yu.V. The dependence of the extractable content and reducing substances of wort of mashing parameters the parameters and composition of the grist. Beer and beverages. 2016; 1: 40-43. [In Russian] https://cyberleninka.ru/article/n/zavisimostekstraktivnosti-i-soderzhaniya-redutsiruyuschihveschestv-susla-ot-parametrov-zatiraniya-i-sostavazasypi/viewer

Bandy L.K., Scarborough P., Harrington R.A., Rayner M., Jebb S.A. Reductions in sugar sales from soft drinks in the UK from 2015 to 2018. BMC Med. 2020, 18(20): 1-10. https://doi.org/10.1186/s12916019-1477-4

Chekina M.S., Meledina T.V., Khlynovskiy M.D. Development of Oats Mashing Technology. Beer and beverages. 2015; 6: 44-48. [In Russian].

Clark M., Macdiarmid J., Jones A., Ranganathan J., Herrero M., Fanzo J. The Role of Healthy Diets in Environmentally Sustainable Food Systems. Food and Nutrition Bulletin. 2020, 41(25): 531-558. https://doi.org/10.1177/0379572120953734

Cornaggia C., Evans D., Draga A., Mangan D., McCleary B. Prediction of potential malt extract and beer filterability using conventional and novel malt assays. J. of the Institute of Brewing. 2019: 125 (3): 294-309. https://doi.org/10.1002/JIB.567

De L., Tulipa D. Healthy food for healthy life. J. of Global Biosciences. 2019, 8(9): 6453-6468. https://www.mutagens.co.in/jgb/vol.08/09/Journal\% 20of\%20Global\%20Biosciences\%20080904.pdf

Derkanosova N.M., Stakhurlova A.A., Pshenichnaya I.A., Ponomareva I.N., Peregonchaya O.V., Sokolova S.A. Amaranth as a bread enriching ingredient. Foods and Raw Materials. 2020; 8(2): 223-231. http://doi.org/10.21603/2308-4057-20202-223-231

Domaretsky V. Technology of extracts, concentrates and beverages from vegetable raw materials (Training manual). Moscow, FORUM. 2011, pp. 117, 162, 166-171, 166-169. Print ISBN: 978-591134-120-6. [In Russian]

Dorsaf H., Sabrine M., Houda B.L., Khémais B.R., Mohsen S., Olfa T. Barley Grass (Hordeum vulgare L.) Protects against Dieldrin-Induced Hyperlipidemia and Hepatorenal Toxicity in Rat. Journal of Food and Nutrition Research. 2020, 8(12): 730-738. https://doi.org/10.12691/jfnr-8-12-6

Emelyanova N.A., Danilevskaya A.V., Koshevaya V.N., Dichenko L.V. Mashing of grain products in the production of polymalt extracts. Technique and technology. 1989; 3: 56-57. [In Russian].

Ermolaeva G.A. Brewery Lab Employee Handbook. St.Peterburg, Profession. 2004. pp. 176-177, 307,
324, 328-330, 332-336. Print ISBN: 5-93913-055-0. [In Russian]

Foley J., Michaux K., Mudyahoto B., Kyazike L., Cherian B., Kalejaiye O., et al. Scaling Up Delivery of Biofortified Staple Food Crops Globally: Paths to Nourishing Millions. Food and Nutrition Bulletin. 2021, 42: 1-17. https://doi.org/10.1177/0379572120982501

Gerasimenko N.F., Poznyakovskiy V.M., Chelnakova N.G. Healthy eating and its role in ensuring the quality of life. Technologies of food and processing industry of agro-industrial complex - healthy food products. 2016; 4(12): 52-57. [In Russian] https://cyberleninka.ru/article/n/zdorovoe-pitanie-iego-rol-v-obespechenii-kachestva-zhizni/viewer

Goode D., Ulmer H.M., Model E.K. Model studies to understand the effects of amylase additions and $\mathrm{pH}$ adjustment on the rheological behaviour of simulated brewery mashes. J. of the Institute of Brewing. 2005; 111 (2): 153-164.

Grachev Yu.P., Plaksin Yu.P. Mathematical methods of planning experiments. (Training manual). Moscow, DeLi print. 2005, 296 p. Print ISBN: 5-94343-096-2. [In Russian]

Kaishev V.G., Seregin S.N. Functional food products: the basis for disease prevention, health promotion and active longevity. Food industry. 2017; 7: 8-14. [In Russian] https://cyberleninka.ru/article/n/funktsionalnyeprodukty-pitaniya-osnova-dlya-profilaktikizabolevaniy-ukrepleniya-zdorovya-i-aktivnogodolgoletiya/viewer

Korotkih E.A., Chusova A.E., Novikova I.V., Astafieva Yu.E. Method of obtaining the highly malt extract. Beer and beverages. 2014; 1: 8-10. [In Russian]. https://cyberleninka.ru/article/n/sposob-polucheniyapolisolodovogo-ekstrakta/viewer

Kosminsky G.I. Technology of malt, beer and soft drinks. Laboratory workshop on technical control production. Minsk, Design PRO. 2001. pp. 159-169. Print ISBN: 985-6182-35-2. [In Russian]

Kriger O.V., Kashirskih E.V., Babich O.O., Noskova $\mathrm{SYu}$. Oat Protein Concentrate Production. Foods and Raw Materials. 2018, 6(1): 47-55. https://doi.org/10.21603/2308-4057-2018-1-47-55

Li C., Jeong D., Lee J.H. Influence of germination on physicochemical properties of flours from brown rice, oat, sorghum, and millet. Food Science and Biotechnology. 2020, 29: 1223-1231. https://doi.org/10.1007/s10068-020-00770-2

Lisitsin A.B., Chernuha I.M., Gorbunova N.A. Scientific support of innovative technologies for healthy foods. Storage and processing of farm products. 2012; 10: 8-14. [In Russian].

Lokhmatova A.A., Kamenskaya E.P. Production of polymalt extract based on barley and wheat malts. 
Materials of the XIX International Scientific and Practical Conference «Modern Problems of Food Production Techniques and Technologies»; 2018 March 22-23, Barnaul, RF. Altai State Technical University named after I.I. Polzunova, Barnaul, 2018, pp. 132-136. [In Russian]

Mikulinich M., Azarenok N., Bolotova P., Guzikova N. Evaluation of nutritional and biological value of polymalt extracts from malts of grain raw materials of the Belarusian selection. Materials of the II International Congress «Science, Nutrition and Health»; 2019 October 3-4, Minsk, BY. ICC of the Ministry of Finance of the Republic of Belarus, Minsk, 2019, pp. 540-547. Print ISBN 978-9857224-76-0. [In Russian]

Mikulinich M.L., Morgunova E.M., Masansky S.L. Selection of optimum technological modes of obtaining malt from different types of Belarusian selection grain for producing polymalt extracts. Bulletin of the Mogilev State University of Food Technologies. 2016; 2(21): 63-74. [In Russian] http://bgut.by/sites/default/files/sites/contents_vestni k_mgup_2016_no2_21.pdf

Morgunova E.M. Development of technology for brewing malt from triticale regionalized in the Republic of Belarus. PhD thesis. Mogilev State University of Food Technologies, Mogilev. 2000, 217 p. [In Russian]

Morgunova E.M., Mikulinich M.L. Complex indicator of quality of polymalt extract depending on fractional structure of grain raw materials. Bulletin of the Mogilev State University of Food Technologies. 2015; 1(18): 15-22. [In Russian]

Panova T.M., Enkenikolay P.V., Yuryev Yu.L. Effect of $\mathrm{pH}$ on enzymatic hydrolysis of barley malt biopolymers. Journal of the University of Technology. 2016: 15(19): 181-183. [In Russian] https://cyberleninka.ru/article/n/vliyanie-rn-nafermentativnyy-gidroliz-biopolimerovyachmennogo-soloda/viewer

Rico D., Peñas E., García M.C., Martínez-Villaluenga C., Rai D.K., Birsan R.I., et al. Sprouted Barley Flour as a Nutritious and Functional Ingredient. Foods. 2020, 9(3): 296. https://doi.org/10.3390/foods9030296

Salar F.J., Agulló V., García-Viguera C., DomínguezPerles R. Stevia vs. Sucrose: Influence on the Phytochemical Content of a Citrus-Maqui Beverage - A Shelf Life Study. Foods. 2020, 9(2): 19. https://doi.org/10.3390/foods9020219

Suboch F. Metodological approaches to the balanced development of competitively cluster-forming platforms of healthy nutrition technologies in the aspect of innovation economics. Agrarian Economy. 2019; 4(287): 2-24. [In Russian] https://www.elibrary.ru/item.asp?id=37526921
Suboch F. Qualitu estimation of food consumption of the population of the republic of Belarus. Economic issues of agriculture development in Belarus. 2020; 48(48): 100-107. [In Russian] https://www.elibrary.ru/contents.asp?id=43122212

Sun J., Xu F., Lu J. A Glycoside Hydrolase Family 62 A-L-Arabinofuranosidase from Trichoderma Reesei and Its Applicable Potential during Mashing

Tsed E.A., Volkova S.V., Koroleva L.M., Yaromich L.P., Haletsky S.P. Influence of digestion regimes on formation of alcohol wort from new grain raw materials of Belarusian breeding. News of universities. Food technology. 2007; 4: 70-71. [In Russian] https://cyberleninka.ru/article/n/vliyanie-rezhimovrazvarivaniya-na-formirovanie-spirtovogo-susla-iznovogo-zernovogo-syrya-belorusskoyselektsii/viewer

Vostrikov S.V., Korotkih E.A., Novikova I.V. Reception of a powdery polymalt extract for functional soft drinks. Beer and beverages. 2011; 2: 14-15. [In Russian] https://cyberleninka.ru/article/n/poroshkoobraznyypolisolodovyy-ekstrakt-dlya-funktsionalnyhbezalkogolnyh-napitkov/viewer 